The published version is at [https://doi.org/10.1016/.pce.2017.04.007] 


\title{
Water Security for Productive Economies: Applying an Assessment Framework in southern Africa
}

\author{
Bunyod Holmatov*a, Jonathan Lautze ${ }^{b}$, Herath Manthrithilake ${ }^{c}$, and Ian Makin ${ }^{c}$ \\ ${ }^{*}$ Corresponding author - International Water Management Institute - Central Asia and \\ Caucasus Office, Apt 123, Bldg 6, Osiyo Street, Tashkent 100000, Uzbekistan. Email: \\ bholmatov@gmail.com \\ ${ }^{b}$ International Water Management Institute - Private Bag X813, Silverton 0127, Pretoria, \\ Southern Africa Office. \\ ${ }^{c}$ International Water Management Institute - Headquarters, 127 Sunil Mawatha, Pelawatte, \\ Battaramulla, Sri Lanka.
}

\begin{abstract}
Achieving water security has emerged as a major objective in Africa, yet an analytical or diagnostic framework for assessing water security in African countries is not known to exist. This paper applies one key dimension of the 2016 Asian Development Bank's (ADB) Asian Water Development Outlook (AWDO) to assess levels of water security for productive economies in countries of the Southern African Development Community (SADC). Economic aspects of water security cover four areas: economic activities in the broad sense, agriculture, electricity, and industry. Water security in each area is measured through application of a set of indicators; results of indicator application are then aggregated to determine economic water security at a country-level. Results show that economic water security in SADC is greatest in the Seychelles and South Africa, and lowest in Madagascar and Malawi. Opportunities for strengthening economic water security in the majority of SADC countries exist through improving agricultural water productivity, strengthening resilience, and expanding sustainable electricity generation. More profoundly, this paper suggests that there is clear potential and utility in applying approaches used elsewhere to assess economic water security in southern Africa.
\end{abstract}

Keywords: water, security, Africa, SADC

\section{Introduction}

Water security has emerged as a critical issue of concern in global, regional and national discourses. Globally, water security has featured in the eighth phase of UNESCO's International Hydrological Programme (UNESCO IHP 2015) and filtered into the conceptualization of Goal 6 of the UN post-2015 Sustainable Development Goal Framework (UN 2015). The topic also receives prominent focus in the mandates of the Global Water Partnership (GWP), the International Water Management Institute (IWMI), and the World Water Council (WWC). Regionally, SADC's Regional Water Policy (2005) and Regional Water Strategy (2006) reference water security and propose concrete actions to ensure it. African Ministers' Council on Water (AMCOW) outlined a path for strategic engagement to strengthen water security in African countries, calling for adoption of a high-level framework of indicators to enable water security assessment, and identifying several indicators that might be used for this assessment (AMCOW et al. 2012). Further, strengthening water security has been recognized as a regional challenge in SADC countries to meet growing food demand of increasing populations under conditions of climate change (Rampa and Wyk 2014). Not surprisingly, water security has also received central focus in regional conferences. The $16^{\text {th }}$ WaterNet/WARFSA/GWP-SA Symposium held in Mauritius in 
October 2015 was focused on "Integrated Water Resources Management and Infrastructural Planning for Water Security in Eastern and Southern Africa."”

Despite the growing importance of the topic, an analytical framework for assessing water security in African countries is not known to exist. In the Asia-Pacific, the Asian Development Bank's (ADB) Asian Water Development Outlook (AWDO) developed and applied a water security assessment framework to Asia-Pacific countries (ADB 2013; 2016). Lautze \& Manthrithilake (2012; 2014a; 2014b) also proposed a water security assessment framework and measured water security in Asia-Pacific countries. Two studies have developed and applied water security assessment frameworks at a global scale (Fischer et al. 2015, Sadoff et al. 2015). Fischer et al. (2015) proposed a water security framework consisting of five indicators and applied the framework to 160 countries; the approach was nonetheless somewhat crude as major aspects of water security - such as environment, storage capacity, water supply and sanitation - appear to have been neglected. Sadoff et al. (2015) adopted a risk-based indicator framework with four headline risks and determined water insecurity from an aggregate of 3 economic risks (excluding ecosystem degradation) in selected countries. An in-depth water security assessment of African countries has not been undertaken.

This paper applies the economic water security dimension of the 2016 AWDO framework to assess levels of water security for productive economies in SADC countries. Economic aspects of water security cover four areas: economic activities in the broad sense, agriculture, electricity, and industry. Water security in each area is measured through application of a set of numerical indicators. The results are then aggregated to determine economic water security at a country-level. Structurally, section 2 of this paper reviews definitions of water security and summarizes existing water security frameworks. Section 3 explains the rationale for applying the AWDO framework to SADC countries; introduces AWDO's economic water security dimension; explains the logic of the indicators; and discusses the data sources used. Section 4 presents the assessment results for SADC countries. Section 5 flags some key issues, discusses the utility of applying AWDO Framework to SADC countries. Section 6 provides general recommendations.

\section{Background: Definitions and Frameworks of Water Security}

More than ten definitions of water security now exist (Appelgren 1997; GWP 2000; Swaminathan 2001; WHO 2003; Cheng et al. 2004; Grey \& Sadoff 2007; Shultz \& Uhlenbrook 2007; Calow et al. 2010; Norman et al. 2011; AMCOW et al. 2012; WaterAid 2012; Grey et al. 2013; Lankford 2013; UNU 2013). While many common elements can be found across these definitions, close scrutiny also reveals noticeable differences in emphasis and breadth. Review of four, more prominent definitions (Box 1), is illustrative of the evolution of the concept over the years. From a base of the first definition (GWP 2000), risk is added to the second (Grey \& Sadoff 2007), and risk is placed at the center of the third (Grey et al. 2013). The fourth definition (UNU 2013) represents an encompassing approach to the water security concept and is utilized in this paper.

\footnotetext{
${ }^{1}$ http://www.waternetonline.org/download//data/download/00000032/Final-16th-Symposium-Programme.pdf
} 
1. Every person has access to enough safe water at affordable cost to lead a clean, healthy and productive life, while ensuring that the natural environment is protected and enhanced (GWP 2000).

2. The availability of an acceptable quantity and quality of water for health, livelihoods, ecosystems and production, coupled with an acceptable level of water-related risks to people, environments and economies (Grey \& Sadoff 2007).

3. A tolerable level of water-related risk to society (Grey et al. 2013).

4. The capacity of a population to safeguard sustainable access to adequate quantities of acceptable quality water for sustaining livelihoods, human wellbeing, and socio-economic development, for ensuring protection against waterborne pollution and water-related disasters, and for preserving ecosystems in a climate of peace and political stability (UNU 2013).

Box 1. Evolution of water security concepts $(2000-2013)$

Several frameworks to assess water security now exist (e.g. Zeitoun 2011; Lautze \& Manthrithilake 2012; Mason \& Calow 2012; ADB 2013, 2016; Lankford 2013; UN-Water 2014; Fischer et al. 2015; Sadoff et al. 2015). Zeitoun (2011) identified six elements of a water security "web": Human/Community Security, National Security, Water Resources Security, Food Security, Energy Security, and Climate Security. Lautze \& Manthrithilake (2012) proposed five components of water security: basic needs, food production, environmental requirements, risk management and independence. Mason \& Calow (2012) developed an overview of a potential framework that covers five themes: resource stress, variability and risk, basic human needs and productivity, environmental needs, and governance. The ADB $(2013,2016)$ framework contains five key dimensions (KDs): household water security, economic water security, urban water security, environmental water security, and resilience to water-related disasters. Lankford (2013) proposed a twodimensional framework constructed from "equity" and "sufficiency" based on six indicators. UN-Water (2014) produced a document focusing on "securing water" that makes reference to five pillars: (i) drinking water, sanitation and hygiene, (ii) water resources, (iii) water governance, (iv) water-related disasters, and (v) wastewater pollution and water quality. Fischer et al. (2015) used five indicators, four of which ${ }^{2}$ were applied to assess hydroclimatic complexity: (i) total renewable water resources per capita; (ii) the ratio of annual water withdrawal to total renewable water resources; (iii) runoff variability; and (iv) the ratio of external to total renewable water resources. Most recently, Sadoff et al. (2015) proposed a set of indicators to quantify four headline risks: (i) droughts and water scarcity; (ii) floods; (iii) water supply and sanitation; and (iv) ecosystem degradation and pollution.

Four of these frameworks have been applied to assess national water security for sets of countries (Lautze \& Manthrithilake 2012; ADB 2013, 2016; Fischer et al. 2015; Sadoff et al. 2015). Lautze \& Manthrithilake (2012) and ADB (2013, 2016) assessed national water security within and across different water use areas, with focus on Asia-Pacific countries. At a global scale, Fischer et al. (2015) applied quantitative indicators to assess country-level 'economic-institutional capacity' and 'hydrological complexity' in 160 countries and placed countries into one of the four hydro-economic classification groups that correspond to level of water security relative to the economic-institutional capacity. Sadoff et al. (2015) applied

\footnotetext{
${ }^{2}$ The fifth indicator - GDP per capita - was applied to assess economic-institutional capacity.
} 
risk-based indicators to determine water insecurity across four headline risks in selected countries.

One issue on which there is no definitive resolution in water security frameworks relates to treatment of institutions. The various frameworks currently in use generally include ends (i.e. outcomes) of water security such as sufficient provision of household drinking water, yet their inclusion of the means (i.e., processes) to achieve water security such as water governance varies. Governance and institutions are clearly important to achieving water security. Nonetheless, it is an open question as to whether these should be part of water security or means to water security. In the AWDO framework, treatment of institutions more closely resembles a discrete means to achieve water security, rather than part and parcel of the concept.

\section{Methods: Applying a key dimension from the AWDO Framework to southern Africa}

The AWDO was initiated by the ADB and the Asia-Pacific Water Forum (APWF) to increase importance of water in Asia Pacific's future development scenarios. Three editions of the outlook report have now been published, in 2007, 2013 and 2016 (ADB 2007 ; 2013; 2016). For the current (2016) version of the report, the authors of this paper developed the approach for the second KD, focused on economic water security, and applied it to 48 Asia-Pacific countries (ADB 2016). Given their familiarity with the approach, the authors sought to apply it to southern Africa in order to explore its utility in other regions. Importantly, the approach contains no regional bias and, as such, is presumed to be applicable in any region.

\subsection{Economic Water Security Framework}

The adopted framework for assessing economic water security consists of four components (Table 1). The first component seeks to measure presence of broad elements that are presumed to enable water's contribution to three economic sectors. The second component examines the degree to which water is secured to enable agricultural production. The third component examines the role of water in electricity production. The fourth component explores water's role in industry. Aggregation of the component scores is taken as the national level of economic water security.

\begin{tabular}{|c|c|c|c|c|}
\hline & $\begin{array}{c}\text { Indicator } \\
\text { Title }\end{array}$ & Indicator Logic & Indicator Measure & Scale \\
\hline \multirow[t]{2}{*}{$\begin{array}{l}\text { Economic } \\
\text { (broad) }\end{array}$} & $\begin{array}{l}\text { Resilience - } \\
\text { assurance of } \\
\text { stable supply } \\
\text { across sectors }\end{array}$ & $\begin{array}{l}\text { Country's economic } \\
\text { activities are more } \\
\text { assured when there is } \\
\text { enough storage to assure } \\
\text { reliable and timely } \\
\text { supply and mitigate risk. }\end{array}$ & $\begin{array}{l}\text { Coefficient of Variation (CV) } \\
\text { of rainfall between and within } \\
\text { years and storage/TRWR } \\
\text { TRWR=Total Renewable } \\
\text { Water Resources }\end{array}$ & $\begin{array}{l}\text { Inter-Annual Rainfall } C V \\
5=\text { less than } 0.025 \\
4=0.025-0.05 \\
3=0.05-0.1 \\
2=0.1-0.15 \\
1=\text { greater than } 0.15 \\
\text { Intra-Annual Rainfall CV } \\
5=\text { less than } 0.2 \\
4=0.2-0.4 \\
3=0.4-0.6 \\
2=0.6-0.75 \\
1=\text { greater than } 0.75 \\
\text { Storage/TRWR } \\
5=\text { greater than } 50 \% \\
4=20-50 \% \\
3=5-20 \% \\
2=3-5 \% \\
1=\text { less than } 3 \%\end{array}$ \\
\hline & Water Stress & $\begin{array}{l}\text { Water that is more } \\
\text { stressed is less } \\
\text { sustainable, more } \\
\text { precarious, and a less }\end{array}$ & $\begin{array}{l}\text { Freshwater } \\
\text { Withdrawal/TRWR }\end{array}$ & $\begin{array}{l}5=\text { less than } 10 \% \\
4=10-20 \% \\
3=20-40 \% \\
2=40-80 \%\end{array}$ \\
\hline
\end{tabular}




\begin{tabular}{|c|c|c|c|c|}
\hline & $\begin{array}{c}\text { Indicator } \\
\text { Title }\end{array}$ & Indicator Logic & Indicator Measure & Scale \\
\hline & & $\begin{array}{l}\text { secure input to economic } \\
\text { activities. }\end{array}$ & & $1=$ greater than $80 \%$ \\
\hline & $\begin{array}{l}\text { Storage } \\
\text { Drought } \\
\text { Duration } \\
\text { (Length) } \\
\text { Index } \\
\end{array}$ & $\begin{array}{l}\text { Countries with higher } \\
\text { capacity to sustain } \\
\text { droughts provide higher } \\
\text { water security to } \\
\text { economic activities. }\end{array}$ & $\begin{array}{l}\text { (Total Dam Capacity/Total } \\
\text { Freshwater Withdrawal per } \\
\text { month)/Mean Annual Drought } \\
\text { Duration }\end{array}$ & $\begin{array}{l}5=\text { greater than } 5 \\
4=3-5 \\
3=1-3 \\
2=0.5-1 \\
1=\text { less than } 0.5\end{array}$ \\
\hline & $\begin{array}{l}\text { Data } \\
\text { Availability }\end{array}$ & $\begin{array}{l}\text { Lack of data obstructs } \\
\text { assessment, monitoring, } \\
\text { decision-making and is } \\
\text { threat to economic } \\
\text { activities. }\end{array}$ & $\begin{array}{l}\text { Availability of } 8 \text { key data } \\
\text { points were assessed : water } \\
\text { storage, groundwater and } \\
\text { surface freshwater } \\
\text { withdrawals, industrial } \\
\text { freshwater } \\
\text { withdrawal, sectoral Gross } \\
\text { Domestic Product (GDP), } \\
\text { water footprint, total } \\
\text { electricity generation, } \\
\text { electricity generation by } \\
\text { source, and monthly country- } \\
\text { level rainfall data }\end{array}$ & $\begin{array}{l}5=\text { all } 8 \text { data points } \\
4=7 \text { data points } \\
3=6 \text { data points } \\
2=5 \text { data points } \\
1=4 \text { or less data points }\end{array}$ \\
\hline \multirow[t]{2}{*}{ Agriculture } & $\begin{array}{l}\text { Water } \\
\text { Productivity } \\
\text { in Agriculture }\end{array}$ & $\begin{array}{l}\text { Productive agricultural } \\
\text { water use allows the } \\
\text { greatest production per } \\
\text { unit of water use, thereby } \\
\text { freeing up maximum } \\
\text { water for other uses. }\end{array}$ & $\begin{array}{l}\text { Agricultural GDP/total } \\
\text { agricultural water withdrawal }\end{array}$ & $\begin{array}{l}5=\text { greater than } \$ 1,000 / \mathrm{km} 3 \\
4=\$ 350-1,000 \text { per } \mathrm{km} 3 \\
3=\$ 200-350 \text { per km3 } \\
2=\$ 100-200 \text { per km3 } \\
1=\$ 0-100 \text { per km3 } \\
\text { Units are in Million } \\
\text { USD } / \mathrm{km} 3\end{array}$ \\
\hline & $\begin{array}{l}\text { Self- } \\
\text { sufficiency of } \\
\text { agricultural } \\
\text { production }\end{array}$ & $\begin{array}{l}\text { Countries that satisfy a } \\
\text { greater proportion of } \\
\text { their agricultural good } \\
\text { consumption from in- } \\
\text { country sources are } \\
\text { considered more secure } \\
\text { and less vulnerable to } \\
\text { global fluctuations in } \\
\text { availability and price. }\end{array}$ & $\begin{array}{l}\text { Ratio of agriculture good } \\
\text { consumption to agricultural } \\
\text { good production. In other } \\
\text { words, this is the net virtual } \\
\text { water imports in agriculture }\end{array}$ & $\begin{array}{l}5=\text { Less than } 0.5 \\
4=0.5-1 \\
3=1-1.5 \\
2=1.5-3 \\
1=\text { greater than } 3\end{array}$ \\
\hline \multirow[t]{2}{*}{ Electricity } & $\begin{array}{l}\text { Achievement } \\
\text { of minimum } \\
\text { platform for } \\
\text { electricity } \\
\text { production }\end{array}$ & $\begin{array}{l}\text { Countries below global } \\
\text { average per capita } \\
\text { electricity production } \\
\text { levels are presumed to be } \\
\text { less water secure as } \\
\text { growth of electricity } \\
\text { production in future may } \\
\text { require increased water } \\
\text { withdrawal, thus creating } \\
\text { a stress on water storage } \\
\text { and potential conflict } \\
\text { with other water uses. }\end{array}$ & $\begin{array}{l}\text { Present per capita electricity } \\
\text { production and the additional } \\
\text { installed capacity needed to } \\
\text { raise per capita power } \\
\text { production to per capita global } \\
\text { average }\end{array}$ & $\begin{array}{l}5=\text { Global average or above } \\
4=\text { within } 10 \text { percent of } \\
\text { global average } \\
3=\text { within } 20 \text { percent of } \\
\text { global average } \\
2=\text { within } 30 \text { percent of } \\
\text { global average } \\
1=\text { more than } 30 \text { percent } \\
\text { below global average }\end{array}$ \\
\hline & $\begin{array}{l}\text { Water } \\
\text { Productivity } \\
\text { in Electricity }\end{array}$ & $\begin{array}{l}\text { Greater productivity } \\
\text { indicates lower water } \\
\text { requirements, and lower } \\
\text { water requirements can } \\
\text { be more easily satisfied } \\
\text { and are therefore more } \\
\text { secure. }\end{array}$ & $\begin{array}{l}\text { GWh production / water } \\
\text { consumption } \\
\text { (country's diversity of } \\
\text { electricity source were linked } \\
\text { to global consumption } \\
\text { averages for those electricity } \\
\text { sources to determine water } \\
\text { consumption associated with } \\
\text { electricity production) }\end{array}$ & $\begin{array}{l}5=\text { Greater than } 100,000 \\
4=50,000-100,000 \\
3=25,000-50,000 \\
2=10,000-25,000 \\
1=\text { Less than } 10,000 \\
\text { Units are in } \mathrm{GWh} / \mathrm{km} 3\end{array}$ \\
\hline
\end{tabular}




\begin{tabular}{|c|c|c|c|c|}
\hline & $\begin{array}{l}\text { Indicator } \\
\text { Title }\end{array}$ & Indicator Logic & Indicator Measure & Scale \\
\hline Industry & $\begin{array}{l}\text { Industrial } \\
\text { Water } \\
\text { Productivity }\end{array}$ & $\begin{array}{l}\text { If productivity of water } \\
\text { in industry is high, its } \\
\text { water allocation will } \\
\text { likely be secure due to its } \\
\text { importance to the } \\
\text { economy. }\end{array}$ & $\begin{array}{l}\text { Industrial GDP/ Industrial } \\
\text { withdrawal }\end{array}$ & $\begin{array}{l}5=\text { greater than } \$ 50,000 \\
4=\$ 20,000-50,000 \\
3=\$ 5,500-20,000 \\
2=\$ 2,100-5,500 \\
1=\text { less than } \$ 2,100 \\
\text { Units are in USD } / 1000 \mathrm{~m} 3\end{array}$ \\
\hline
\end{tabular}

Table 1: Economic Water Security Framework (ADB 2016)

Methods used to assess economic water security in each of the four components of the framework are discussed below. Broadly, each component contains a set of indicators that were populated. Results of indicator application were placed on a scale of 1 to 5 according to absolute scales shown in the right column of table 1. A score of 5 represents greater water security and 1 represents less water security. Indicator scores were added to produce a score for each component. ${ }^{3}$

To determine overall levels of water security in particular countries, indicator results were averaged within components to produce a score for each component on a 1 through 5 scale. Averaged component scores were then added to generate overall country scores on a 20 point scale (i.e., a composite of 4 components that are each on a 5 point scale). Alternate ways to aggregate component results certainly exist, for example, results in particular components can be weighted according to their importance. Nonetheless, while weighting can enable an assessment of water security that allocates appropriate importance to indicators that is best matched with local realities, application of weights brings complexity that holds potential for introduction of subjectivity and bias. As such, un-weighted addition of results in particular components was felt to be the more transparent and desirable option; it is also an option consistent with approaches utilized in ADB (2013; 2016).

As scores ranged from 1 to 5 for each component, the maximum score a country could achieve was 20 and the minimum was 4 . A higher score indicates greater water security in a particular country. The country scale assessment was chosen for two main reasons: a) data is generally available at country scale; and b) ultimately, major economic policy decisions are taken by sovereign nations.

Data Data were obtained from a combination of recent sources (e.g. Hoekstra \& Mekonnen 2012; Harris et al. 2014; IEA 2015; USEIA 2015; WB 2015; FAO AQUASTAT 2015). To the extent possible, data were harmonized to the year 2013. Specific data sources in each component are explained in the context of each component, immediately below.

\subsection{Economic (broad)}

Resilience - The degree to which countries have achieved assurance of stable supply across sectors was assessed by coupling of results of two indicators: (i) rainfall coefficient of variation between and within years; and (ii) storage divided by total renewable freshwater resources. ${ }^{4}$ A lower coefficient of variation of rainfall and higher ratio of storage to total renewable freshwater resources indicate that a country is more resilient to sudden changes. Conversely, a higher coefficient of variation of rainfall and lower ratio of storage to total renewable freshwater resources indicate that a country is less prepared to respond to fluctuations of water availability. Data from Harris et al. (2014) on the monthly, country-level

\footnotetext{
${ }^{3}$ Total scores varied across components and are explained in the figure captions.

${ }^{4}$ Total renewable water resources includes both internal and external renewable water resources (see FAO AQUASTAT, 2015). The external renewable water resources available to a particular country is an estimation.
} 
precipitation for the period of 1901 - 2013 and the FAO AQUASTAT (2015) data on the total country's dam capacity and total renewable water resources was utilized. The latest available data on the total renewable water resources was from 2014 and used for calculations. The latest data on country's dam capacity was from 2010, with exception of Seychelles. For the purpose of this report, we assume there has been no significant change in storage capacities since the last year of data.

Water Stress Total freshwater stress is measured as total annual freshwater withdrawal divided by total renewable freshwater resources. A lower proportion of renewable water resources that are withdrawn indicate greater water security for economic growth and production. Data from the WB (2015) on the total annual freshwater withdrawals and the FAO AQUASTAT (2015) on total renewable freshwater resources were utilized. The latest available data on the total annual freshwater withdrawals from 2013 was used in the calculations. The FAO AQUASTAT (2015) data on total renewable freshwater resources for each country remained constant across years (e.g. constant in 2002, 2007, 2012, and 2014), thus we used the 2014 data.

Storage Drought Duration Index Assessment of countries capacity to sustain droughts was conducted in two steps: i) determining number of months that countries dam capacity is able to provide reliable water supply; ii) dividing the number of months with reliable water supply by mean annual drought duration. Higher proportion of months with reliable water supply indicates greater water security for economic activities. This indicator was derived from Eriyagama et al. (2009). Data from New et al. (2002) on mean annual drought duration was utilized. The latest available WB (2015) data on the total annual freshwater withdrawals from 2013 was used in the calculations. Data on the total country's dam capacity was obtained from the FAO AQUASTAT (2015).

Data Availability Data availability was measured by the degree to which data were available to populate the indicators applied in this framework. Eight data points were considered central for the calculations and their availability for each country was assessed: data on water storage (FAO AQUASTAT 2015), groundwater and surface freshwater withdrawals (FAO AQUASTAT 2015), sectoral freshwater withdrawal (WB 2015), sectoral GDP (WB 2015), water footprint (Hoekstra \& Mekonnen 2012), electricity generation (IEA 2015; and USEIA 2015), electricity generation by source (IEA 2015), ${ }^{5}$ and monthly, countrylevel rainfall data (Harris et al. 2014).

\subsection{Agriculture}

Water productivity in agriculture Water productivity in the agriculture sector was measured by agricultural GDP divided by average agricultural evapotranspiration (AgrET). Greater agricultural water productivity indicates higher water security. Data on the agricultural percent of value added to GDP and the total GDP in year 2013 was obtained from the WB (2015) ${ }^{6}$. To estimate AgrET at country-level, annual actual evapotranspiration (ET) data was obtained from the MODIS Global Evapotranspiration Project (MOD16) for 2013 (MOD16 Nd) and compared with actual ET dataset for yearly actual ET available on the FAO Geonetwork website (FAO 2015). Cultivated land area ${ }^{7}$ data for 2013 was then obtained from the Global Agro-Ecological Zones (GAEZ) (IIASA and FAO 2015). Finally, AgrET for

\footnotetext{
${ }^{5}$ Although the U.S. Energy Information Administration (2015) and the WB (2015) contained relevant data, they lacked the degree of detail necessary for our calculations and were excluded from consideration.

${ }^{6}$ The agricultural value added to GDP for Swaziland was extrapolated to 2013 using linear trends.

${ }^{7}$ Cultivated land area refers to both irrigated and rainfed areas.
} 
cultivated land was clipped from the MOD 16 global ET dataset using the geographic information system (GIS). ${ }^{8}$ Actual AgrET for every country was averaged to estimate country AgrET in mm/year. The volume of AgrET $\left(\mathrm{km}^{3}\right)$ was determined by first converting the AgrET in $\mathrm{mm} /$ year to $\mathrm{km} /$ year and multiplying by the cultivated land area $\left(\mathrm{km}^{2}\right)$. The estimated AgrET covers both rainfed and irrigated areas for the selected countries.

Self-sufficiency of agricultural production Sufficiency of agricultural production is measured as the annual water footprint of agricultural good consumption divided by annual water footprint of agricultural good production. National scale annual water footprint statistics data on agricultural good consumption and agricultural good production ${ }^{9}$ from Hoekstra \& Mekonnen (2012) was used. Both internal and external water footprints were added to determine country-level total water footprint of agricultural good consumption. Given that the annual water footprint data from Hoekstra \& Mekonnen (2012) reflected the situation up to the year 2005, their data was extrapolated to 2013 using secondary indicators. The annual water footprint data on agricultural good consumption was extrapolated to 2013 based on population change. The country-level population data was obtained from the WB (2015). The annual water footprint data on agricultural good production was extrapolated to 2013 by multiplying 2005 country value by the ratio of the respective country's agricultural GDP change between 2005 and 2013. ${ }^{10}$

\subsection{Electricity}

Minimum Platform, Electricity Production - the degree to which the minimum platform for electricity production is achieved was measured by subtracting country's percapita electricity production from the global average per-capita electricity production. To calculate per-capita electricity production in individual countries and globally, the 2012 population data was obtained from the WB (2015) and combined with the 2012 data on electricity production from the U.S. Energy Information Administration (USEIA 2015). A higher value indicates that a country is less water secure as it needs to increase electricity production which translates to more additional capacity to achieve the minimum platform of per-capita electricity production whereas a lower value indicates that a country's electricity production is closer to the global average, hence less additional capacity is needed.

Water Productivity in Electricity Water productivity of electricity was measured as electricity production $(\mathrm{GWh})$ divided by the quantity of water consumed $\left(\mathrm{km}^{3}\right)$ to produce that electricity. Estimated electricity production data was obtained from the International Energy Agency (IEA 2015), which for 2013 contained the most detailed data on country's electricity production from 13 electricity sources, ${ }^{11}$ namely : coal, oil, gas, biofuels, waste, nuclear, hydro, geothermal, solar photovoltaic, solar thermal, wind, tide, and category named "other sources." Diversity of a country's electricity sources was then linked with indicative quantities of water consumption of those sources (Gerbens-Leenes et al. 2008; IPCC 2012; Mekonnen et al. 2015). For consistency in calculations, the following three assumptions were made:

\footnotetext{
${ }^{8}$ GAEZ and MOD16 datasets were used because they were believed to be more precise than the FAO estimates. ${ }^{9}$ Agricultural good production excludes water footprint of grazing and animal water supply.

10 The agricultural value added to GDP and total GDP data was obtained from the WB (2015). The agricultural value added to GDP for Swaziland was estimated for 2013 by linearly extrapolating from earlier years for which data were available.

${ }^{11}$ Data were available for 10 countries, but no data were available for Lesotho, Madagascar, Malawi, Seychelles, and Swaziland.
} 
1) The median water consumption rather than the lowest or the highest values were used to calculate water footprints of electricity derived from coal, gas, nuclear, geothermal, solar photovoltaic, solar thermal, and wind sources.

2) Water consumption for electricity generation from biofuels (described by the International Energy Agency only as the total of solid biofuels and biogas) was assumed to be equal to the water consumption for electricity generation from biomass, and the water footprint for biomass derived electricity (average data from Brazil, Netherlands, US, and Zimbabwe) was obtained from GerbensLeenes et al. (2008).

3) Water consumption for hydropower is affected by the reservoir design, climate and allocation to other uses (IEA 2012). To obtain a more global average of water consumption of hydro-electricity the median IPCC (2012) values were utilized in calculations.

Ultimately, countries' water productivity in electricity was calculated by dividing the total electricity production by the total water consumption in electricity generation. The total water consumption in electricity generation for each country was calculated by adding water consumed to produce electricity from each of the 8 sources. ${ }^{12}$ Higher values indicate that a country is using less water per unit of electricity generated and presumed to be more water secure as it is using water efficiently.

\subsection{Industry}

Industrial Water Productivity Industrial water productivity is measured as the industrial GDP divided by industrial water withdrawal. The latest available industrial value added to GDP, total GDP, industrial freshwater withdrawal (as percent of total) and total annual freshwater withdrawal data was obtained from the WB (2015). ${ }^{13}$ A higher proportion of industrial GDP to industrial water withdrawals indicates that productivity of water in industry is high and the water allocation will likely be secure due to its importance to the economy.

Data limitations In SADC member states, data availability ranged from moderate to good as captured by the data availability indicator. Most data gaps were detected in surface and groundwater withdrawals that were not utilized in calculations and in diversity of electricity sources. Data on the diversity of electricity sources was not available for five countries: Lesotho, Madagascar, Malawi, Swaziland and Seychelles. The country-level data on total renewable water resources could not be obtained for Seychelles. Agricultural and industrial value added to GDP for 2013 were not available for Swaziland. Missing agricultural and industrial value added to GDP data were in-filled by linear extrapolation to 2013 for Swaziland.

\section{Results}

Countries' overall economic water security was determined as composite scores of the four components: economic (broad), agriculture, electricity, and industry. The score for each component is derived from the numeric indicators described above. Section 4.1 presents the overall results and aggregate component scores for each country. Section 4.2 presents indicator rankings within each of the four components.

\footnotetext{
${ }^{12}$ None of the SADC countries generated electricity from waste, geothermal, solar thermal, tide, or unspecified "other sources" and hence 8 electricity generating sources remained.

13 The industrial value added to GDP for Swaziland was extrapolated to 2013 using the linear extrapolation as was discussed above.
} 


\subsection{Overall Results}

Review of the aggregated scores across countries indicates reasonable dispersion in economic water security in SADC. Economic water security indeed ranges from 9.0 to 15.3 on a 20 point scale (Fig 1). South Africa and the Seychelles appear to be the most economically water-secure; Madagascar and Malawi appear to be the least economically water-secure. All countries show room for improvement. Entry points for improvement in many countries may lie in the agriculture and electricity sectors.

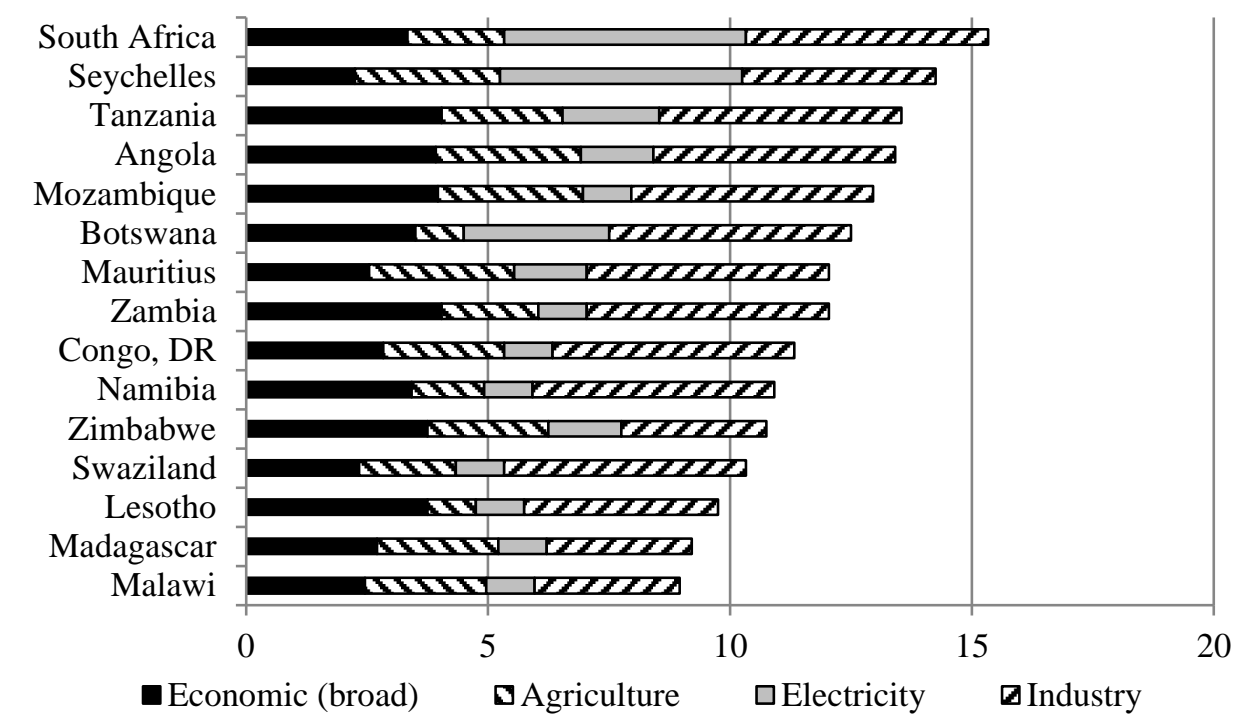

Fig 1. Economic Water Security levels in SADC countries. Overall range is between 4 and 20. Maximum for each component is 5. Extrapolation was used in agriculture and industry if insufficient data.

\subsection{Component Results}

Economic (broad) Results in the broad economic component range from 9.3 to 16.2 out of 20 (Fig 2). ${ }^{14}$ Levels of resilience in SADC countries can be frequently described at moderate to low. Countries such as Congo DR, Madagascar, Malawi, and Namibia appear quite vulnerable to rainfall fluctuations. Levels of water stress in SADC countries, conversely, often appear manageable. Mauritius, South Africa, Swaziland and Zimbabwe place the greatest pressure on their resources, but water stress may be less of an issue in the remainder of SADC countries. Most required data were available in most SADC countries.

Agriculture Agriculture results ranged from 2 to 6 out of 10 (Fig 3). With the exception of Seychelles and Mauritius, agricultural water productivity in SADC countries is low and may constitute the largest shared challenge in the region. ${ }^{15}$ Agricultural selfsufficiency in southern African countries is varied. While the majority of countries in the region appear in at least average position in this regard, dependence on agricultural imports in Botswana, Lesotho, Mauritius, Namibia and the Seychelles may render such countries vulnerable to fluctuations in availability and price - compromising their economic water security. Such countries may explore ways to increase self-sufficiency in order to mitigate risks associated with external dependence.

\footnotetext{
14 This statement excludes the Seychelles, omitted here due to data limitations.

${ }^{15}$ ReSAKSS (2015) provides additional information on the importance of the agriculture sector and share of SADC agriculture GDP by country.
} 
Electricity Economic water security in electricity is widely varied across southern African countries (Fig 4). South Africa perform well, Botswana and Seychelles somewhat mediocre, and the remainder of countries show notable room for improvement. Aside from South Africa and the Seychelles, all countries appear to face major shortfalls in electricity production and future expansions may encroach on water supplies - such encroachment, in turn, will need to be carefully planned so as not to compromise productivity in other sectors. Aside from Botswana and South Africa, virtually all SADC countries can improve their water productivity in electricity.

Industry Water security in industry can be described as moderate to good in southern Africa (Fig 5). SADC countries appear to be at least average in the component. The greatest improvement may be needed in Madagascar, Malawi and Zimbabwe. Nonetheless, a comparison of results in this component with results in other components suggests that the region's greatest economic water security challenges may lie elsewhere.

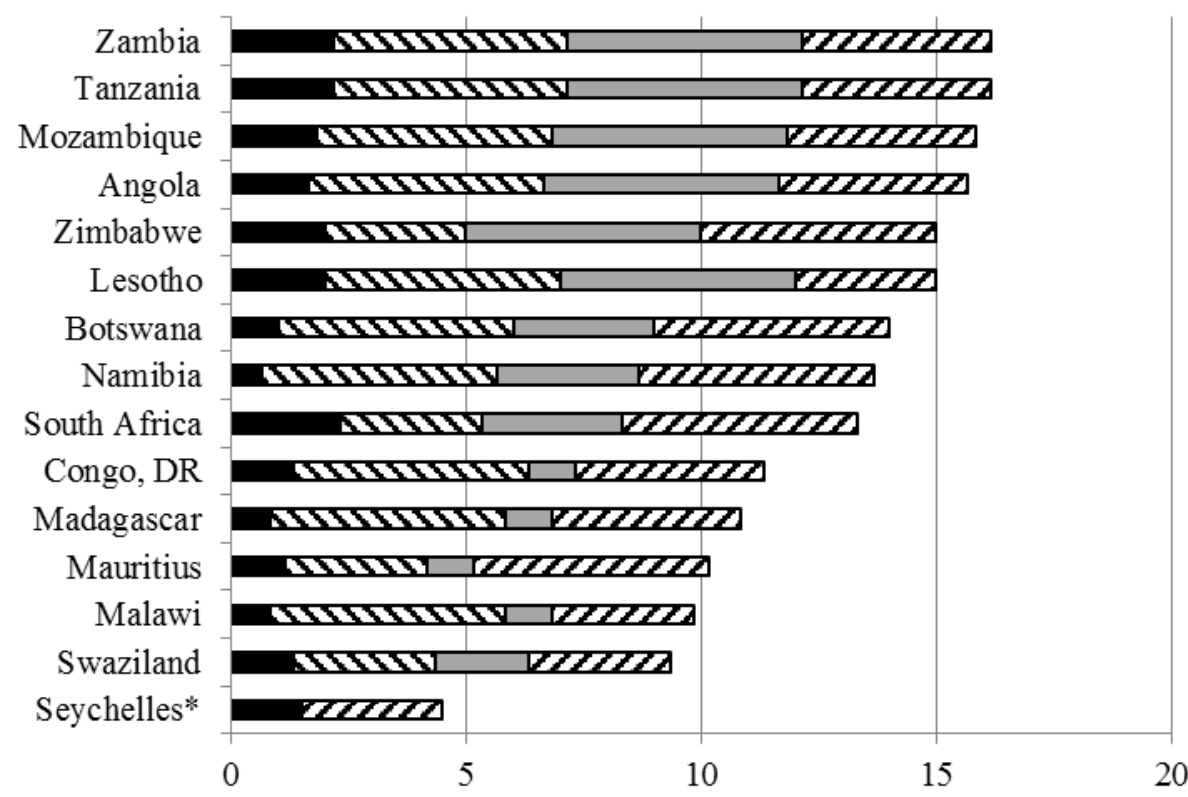

$\boldsymbol{\square}$ Resilience $\mathbf{\nabla}$ Freshwater Stress $\square$ Storage Drought Duration $\square$ Data Availability

Fig 2. Results in the broad economic component. Maximum for each indicator is 5. Overall maximum score for the component is $20 .{ }^{*}$ Seychelles lacked data for 2 indicators. 


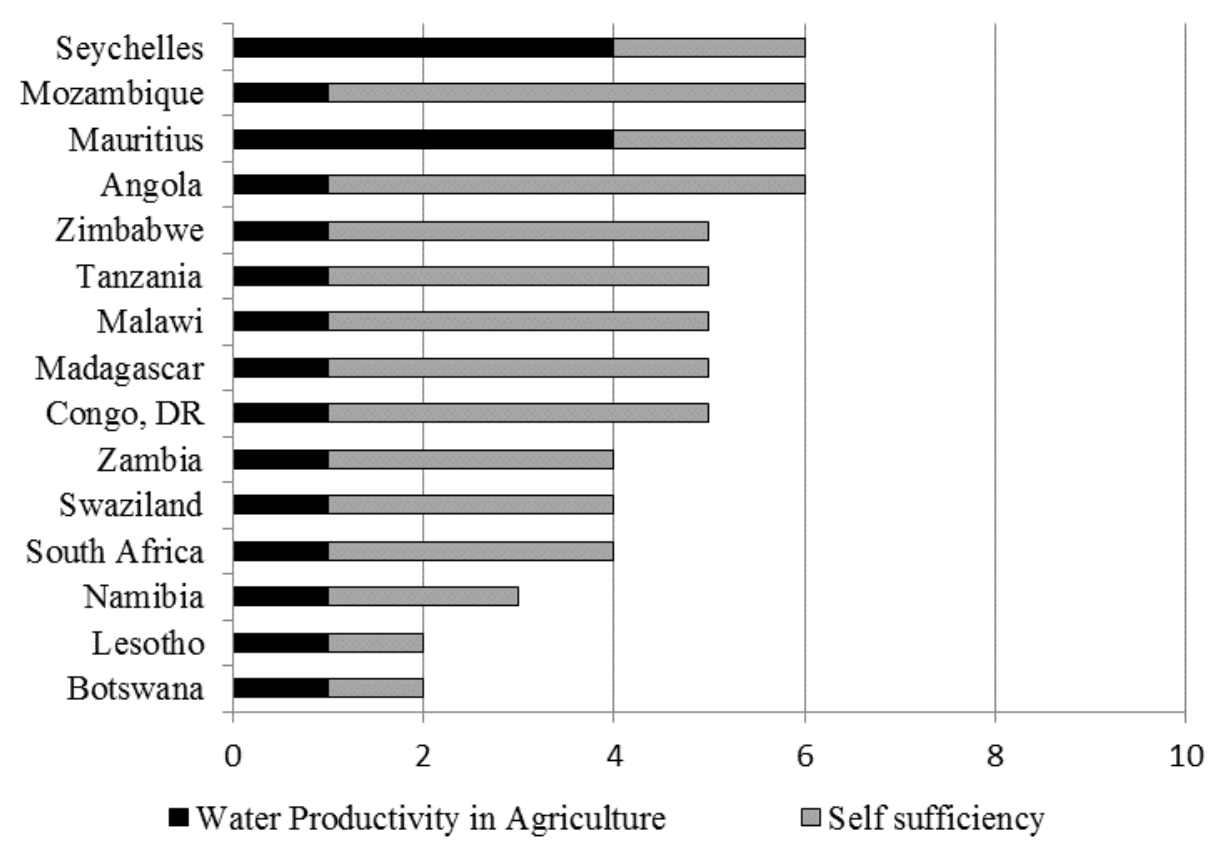

Fig 3. Results in the agriculture component. Maximum for each indicator is 5. Overall maximum score for the component is 10 .

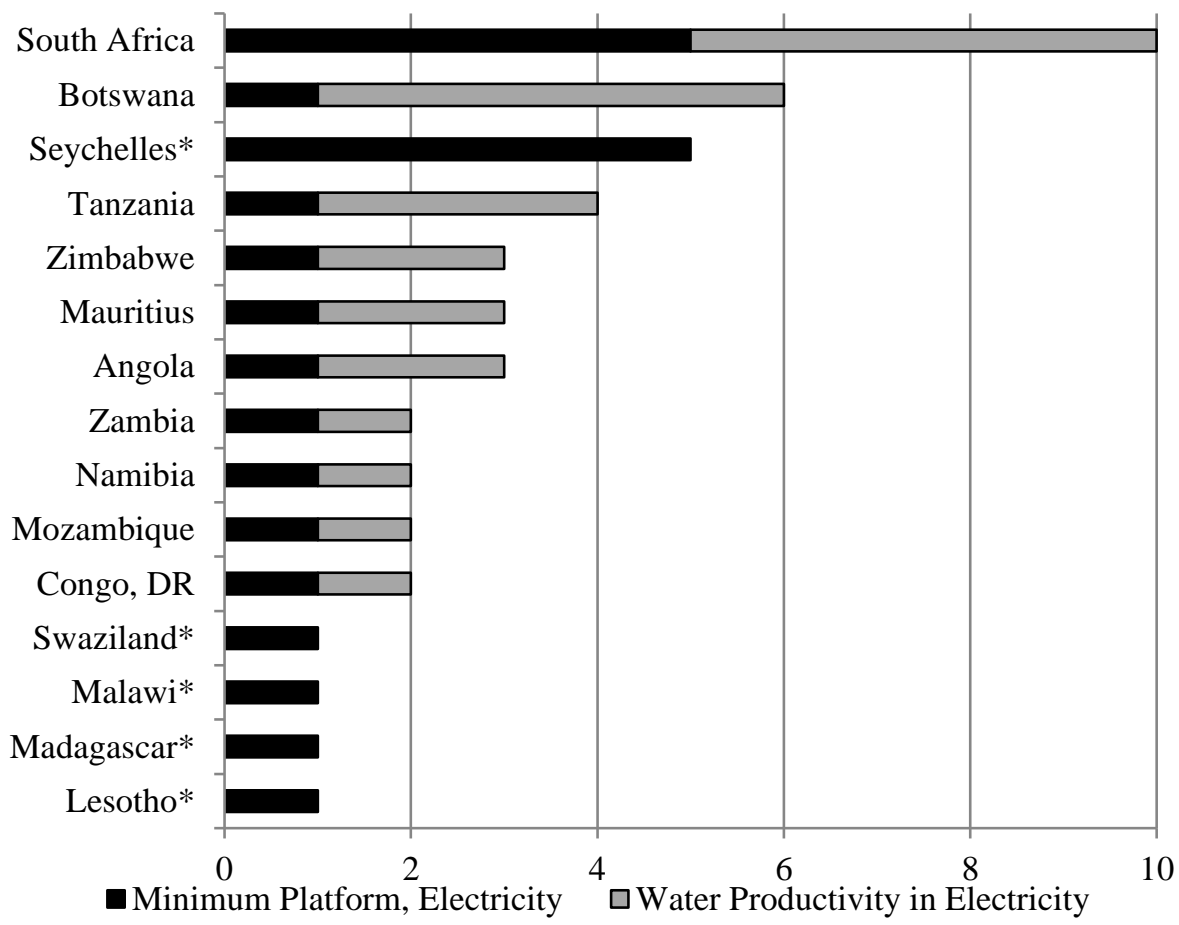

Fig 4. Results in the electricity component. Maximum for each indicator is 5. Overall maximum score for the component is 10 . *Insufficient data for 1 indicator. 


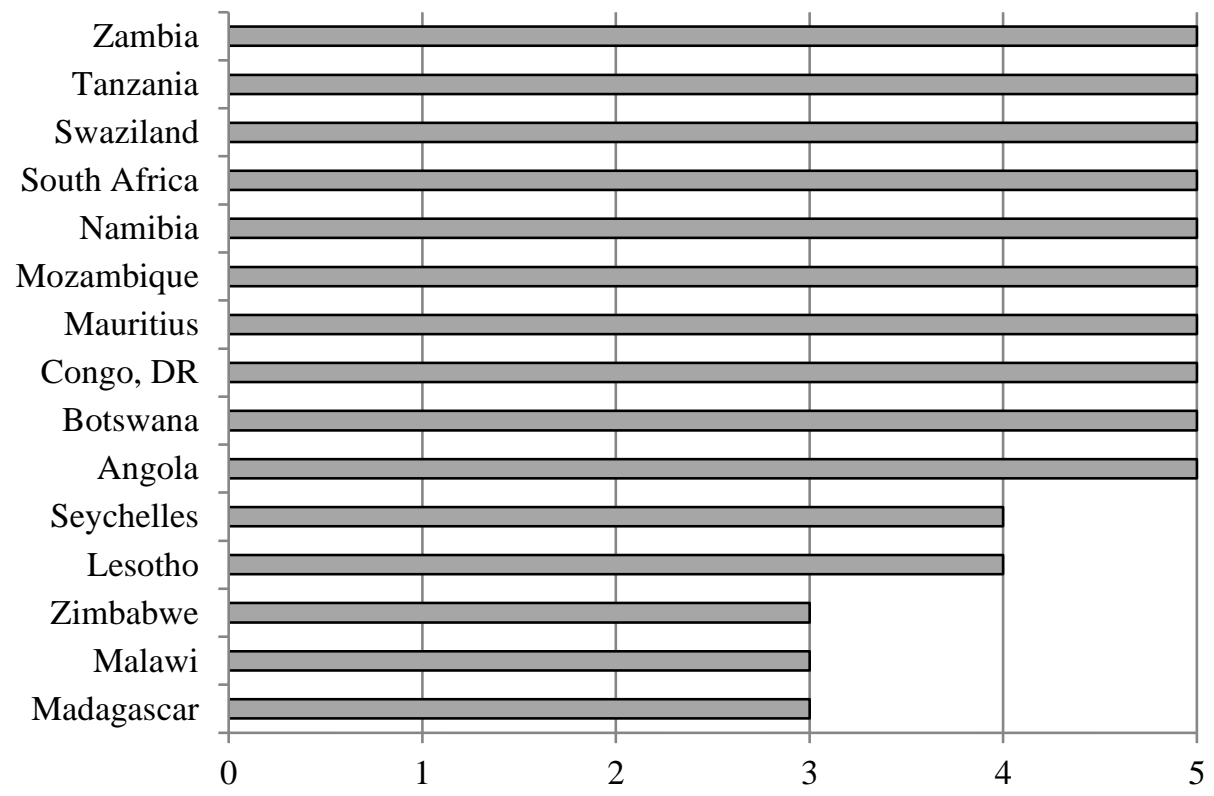

Fig 5. Results in the industry component. Higher ranking indicates more security.

\section{Discussion}

This work applied one key dimension of ADB's AWDO 2016 Framework to assess levels of economic water security for productive economies in SADC countries. This work provides a basis for moving beyond broad calls for achieving water security in Africa, to provide a framework to actually measure economic water security at a country-level and across four economic components within countries. The results highlight important variation in levels of economic water security in SADC countries; with Lesotho, Madagascar, Malawi and Swaziland having the greatest potential to improve.

Our findings reveal substantially less water security than that presented in Fischer et al. (2015). Our results reveal somewhat varied level of water security in SADC. By contrast, results of Fischer et al. (2015) suggest that all SADC countries are water secure, with the exception of Zimbabwe. In particular, our methods determined Malawi to be the most water insecure in SADC according to our approach, and was at substantial risk of water insecurity by Sadoff et al. (2015). In contrast, results of Fischer et al. (2015) suggests that Malawi is water secure. ${ }^{16}$ Part of the explanation for such inconsistency between our results and results of Fischer et al. (2015) may relate to the reality that our approach was focused on economic water security specifically whereas the aim of Fischer et al. (2015) was to assess water security broadly. Another part of discrepancy may relate to deficiencies in the methods applied by Fischer et al. (2015); for example, consideration of storage capacity and environmental preservation, presumably important parts of water security, were somehow omitted from their methods. Further, "hydrological complexity", applied as the central measure of a country's water security in Fischer et al. (2015), is composed of only 4 indicators. The degree to which populating just 4 indicators can be said to reflect the level of a country's water security as a whole is no doubt somewhat questionable.

Findings generated in this paper reveal specific areas of strength and vulnerability in SADC countries. Three areas of strength in SADC countries are: i) acceptable level of freshwater stress; ii) moderate to good data availability; and iii) moderate to good industrial production. In contrast, three areas that require strengthening are: i) improving resilience, ii)

\footnotetext{
${ }^{16}$ Fischer et al. (2015) only covered 13 SADC countries, and excluded the Seychelles and Mauritius.
} 
raising agricultural water productivity, and iii) increasing electricity production. Although the approach utilized in this paper may be imperfect and cover only one aspect of water security, it is the first of its kind to directly assess levels of water security in southern African countries.

This paper suggests potential for applying - either directly or in adapted form - the ADB's AWDO approach to assess economic water security in southern Africa as a low-cost, multi-sectoral screening tool. The results provide guidance for decision makers and resource managers to identify where water insecurity is most critical and where investment may be targeted to enhance water security. For example, SADC countries can improve their water security by strengthening three areas of vulnerability while reinforcing progress in areas of strength.

Application of the economic water security framework in southern Africa has helped to reveal at least four key issues stemming from application of the framework. First, transboundary waters are central to water management in SADC, perhaps more so than other regions, and may not have been fully captured in the framework utilized. TRWR, utilized in this paper, accounts for inflow and outflow secured through formal and informal treaties or agreements from transboundary waters to a particular country. However, use of TRWR does not distinguish between a country that depends on flows generated internally (which is presumably more secure) from a country that depends on flows generated internally and externally (which is presumably less secure). Considering that shared waters involve competing uses where an upstream country's overuse of its allocation reduces "secured" inflow to the downstream country, the actual quantity of TRWR in a particular downstream country may not always match the data. As such, there may be a need to more comprehensively capture degree of inclusion and reliance on transboundary waters in a water security framework for the region.

Second, related, there may be a need to explicitly accommodate the fact that the most biophysically suitable sites for water storage development that benefit a particular country, may lie in the country's upstream neighbour. And recommendations for increased water storage in particular countries that have been made in this paper, may effectively be treated as recommendations for increasing storage that benefits that country but may not necessarily be physically in a country. Ultimately, realities related to transboundary waters in southern Africa may confound country-based frameworks utilized elsewhere.

Third, there are clear synergies within and across dimensions of water security. In the economic water security framework applied in this paper, it may be a challenge to achieve high performance in all four components of the utilized framework because the competing sectoral demands are often at odds. Realization of forward-leaning nexus approaches - rarely evidenced at this point - may help to optimize water use across sectors. Related, this paper placed focus on only one of five dimensions of water security, which may have masked the need for sustainable approaches that enhance economic water security without imposing costs on other areas, such as the environmental water security. A next step could be to apply other dimensions of water security in conjunction with this dimension, and to adapt the overall framework to Africa context.

Fourth, it may be worthwhile to consider subnational variation, e.g., in agricultural practices and climate. The methods utilized in this paper reflect nationally-averaged agriculture conditions in SADC countries, and in reality there is large variation within countries in terms of agricultural practices, climate and physical conditions. Subnational assessments would indeed help to capture this variation. 


\section{Conclusion}

Based on the results of the assessment in SADC countries, we provide three recommendations. A first recommendation is to improve agriculture water productivity, resilience, and sustainable electricity generation as means to raising overall levels of economic water security. The agriculture sector in SADC is vulnerable as seen from the effects of recent droughts (Mpala 2015) and targeted interventions are urgently needed. These interventions should include focus on agricultural water productivity that can be improved through elevating efficiency of water delivery infrastructure, better field management practices, use of improved seed varieties, and optimal use of fertilizers. Resilience can be improved by expanding storage capacity and expanding use of techniques such as managed aquifer recharge. Sustainable electricity generation can be improved through expanding the share of renewable electricity sources that are less water intensive than conventional electricity sources, such as wind, solar, geothermal. Notably, Seychelles has developed a target to generate 5\% of its final energy from renewable energy by 2020 and increase it to $15 \%$ by 2030 (Razanajatovo 2014).

A second recommendation is to place continued emphasis on three areas where SADC countries are performing well. Addressing vulnerable areas does not preclude continued emphasis on areas of strength: namely, monitoring and assessment of water resources, efficient use of water in industrial production, and appropriate management of freshwater stress. Regional principles and strategies described in the SADC Regional Policy (SADC 2005), SADC Regional Strategy (SADC 2006), and the recent SADC Industrialization Strategy and Roadmap 2015-2063 (SADC 2015), highlight considerable scope for meeting all three objectives. For example, tapping region's industrial potential may create opportunities to upgrade water supply infrastructure, utilize water efficient technology base, and strengthen environmental safeguards including promotion of water use and quality standards. Regional strategies aimed towards promoting water efficiency across sectors, upgrading and improving water infrastructure (SADC 2006) could help to alleviate the effects of freshwater stress in the region. Greater implementation of a policy statement encouraging water sector monitoring and evaluation at multiple levels (i.e. Policy 9.1.4., SADC 2005) could increase availability of reliable data.

A third recommendation is to utilize an analytical water security framework such as this to develop an evidence base to help downscale regional policies to national contexts, and match regional policies to regional needs. The SADC regional water policy (2005), for example, calls for investments in inter-basin transfers, large scale water distribution networks and storage dams to ensure water security. Similarly, the SADC regional water strategy (2006) links development of dams with increased water security. Although these investments would contribute to increasing water security in the region, identification of the relative importance of the various interventions in specific country contexts could be informed by application of a water security framework. For example, investments to increase dam capacity may be most needed in Congo DR, Madagascar, Malawi, Mauritius and Namibia that scored lowest in resilience and storage relative to drought duration. Meanwhile, Lesotho and Botswana may require greater investment in raising self-sufficiency and productivity in agriculture.

These recommendations have important implications for the regional economic integration, in that they may highlight areas to facilitate exchange of best practice regarding water use in selected sectors and strengthen national capacity to make more efficient use of water resources. All three recommendations could help to transfer knowledge and 
methodologies between countries to optimize and equitably share water derived benefits among regional member states.

Three caveats should be mentioned before concluding. First, the methods utilized in this paper combined a set of water resources and economic data to measure economic water security in SADC countries. Some of the economic data -e.g., sectoral GDP - no doubt reflect the effects of policies beyond water management. Nonetheless, the bottom line is that the productivity of water use - widely accepted as an important indicator in the water sector (e.g., FAO 2003; Kijne et al. 2003; Molden 2007) - is affected by decisions outside the water sector. Related, second, there are no doubt interdependencies across components and indicators. A broad economic context for water security for example, can help to enable water security in agriculture, energy, and industry. And some of the conditions that enable improved agriculture water security likely help to enable improved energy security. Such inter-relationships likely affected results and alternate approaches - such as measuring economic water security as the lowest score of the four components - were considered. Ultimately, however, this paper sought to adopt identical methods to those used in ADB (2016) and as such added scores for the four components. Third, lack of data for some countries prevented population of all indicators in the broad economic and electricity components; in such cases, component scores for such countries were determined based on the indicators that were in fact populated. Inability to populate all indicators may have affected results in two components.

In conclusion, application of the economic water security dimension of an updated 2016 AWDO approach to SADC has helped reveal levels of economic water security across the region's countries and identify strengths and vulnerabilities within individual countries. Overall, economic water security in southern Africa is variable with many opportunities for improvement. Areas for improvement include increasing resilience, improving agricultural water productivity, and improving sustainable electricity production. Refining and reapplying a framework such as that outlined in this paper may play a critical role at a national and regional level by providing evidence to assess, plan and target water use policies and interventions across elements central to economic water security.

Acknowledgements The authors wish to acknowledge that the approach applied in this paper was developed as part of the process for creating the ADB Asia Water Development Outlook. Further, the authors wish to thank Anil Terway for input provided to the measurement framework used in Key Dimension 2: economic water security.

\section{References}

ADB (Asian Development Bank). (2007). Asian Water Development Outlook 2007. Available from: https://www.adb.org/publications/asian-water-development-outlook2007 (Accessed on 08/02/2017)

ADB (Asian Development Bank). (2013). Asian Water Development Outlook 2013. Available from: http://www.adb.org/sites/default/files/publication/30190/asian-waterdevelopment-outlook-2013.pdf (Accessed on 21/12/2015).

ADB (Asian Development Bank). (2016). Asian Water Development Outlook 2016. Available from: https://www.adb.org/sites/default/files/publication/189411/awdo2016.pdf (Accessed on 20/09/2016).

AMCOW, CDKN, and GWP. (2012). Water Security and Climate Resilient Development: Technical Background Document. Available from: http://www.wcdrr.org/wcdrrdata/uploads/867/Water\%20security\%20and\%20climate\%20resilient\%20developmen 
t_Tech\%20background\%20doc\%20(AMCOW\%20and\%20GWP\%202012)\%20Englis h.pdf (Accessed on 21/12/2015).

Appelgren, B. (1997) 'Keynote paper - Management of Water Scarcity: National water policy reform in relation to regional development cooperation', Second Expert Consultation on National Water Policy Reform in the Near East. Cairo, 24-25 November 1997. Keynote paper - Management of Water Scarcity: National water policy reform in relation to regional development cooperation, FAO, Rome.

Calow, R. C., MacDonald, A. M., Nicol, A. L., \& Robins, N. S. (2010). Ground water security and drought in Africa: linking availability, access, and demand. Groundwater, 48(2), 246-256.

Cheng, J., Yang, X., Wei, C., Zhao, W. (2004). Discussing water security. China Water Resources, 1: 21-23.

Eriyagama N., Smakhtin V., \& Gamage N. (2009). Mapping Drought Patterns and Impacts: A Global Perspective. IWMI Research Report 133. Sri Lanka: Colombo.

FAO (Food and Agricultural Organization of the United Nations). (2003). Why agricultural water productivity is important for the global water challenge. Available from: http://www.fao.org/docrep/006/y4525e/y4525e06.htm\#bm06 (Accessed on 22/09/2016).

FAO (Food and Agricultural Organization of the United Nations). (2015). GeoNetwork Database. Available from: http://data.fao.org/database?entryId=b54079fb-b1c0-4dfe9f2a-4992c18e88aa (Accessed on 15/02/2015).

FAO AQUASTAT (Global Water Information System of Food and Agricultural Organization of the United Nations). (2015). AQUASTAT. Available from:

http://www.fao.org/nr/water/aquastat/data/query/index.html (Accessed on 22/06/2015).

Fischer, G., Hizsnyik, E., Tramberend, S., and Wiberg, D. (2015). Towards indicators for water security - A global hydro-economic classification of water challenges.

International Institute for Applied Systems Analysis: Interim Report IR-15-013. Available from: http://www.iiasa.ac.at/publication/more_IR-15-013.php (Accessed on 21/12/2015).

Gerbens-Leenes, P. W., Hoekstra, A. Y., \& Meer, T. H. (2008). Water footprint of bio-energy and other primary energy carriers.

Grey, D., \& Sadoff, C.W. (2007). Sink or swim? Water security for growth and development. Water Policy 9, 545-571.

Grey, D., Garrick, D., Blackmore, D., Kelman, J., Muller, M., \& Sadoff, C. (2013). Water security in one blue planet: twenty-first century policy challenges for science. Philosophical Transactions of the Royal Society of London A: Mathematical, Physical and Engineering Sciences, 371(2002), 20120406.

GWP (Global Water Partnership). (2000). Towards Water Security: A Framework for Action. GWP, Stockholm.

Harris, I., Jones, P. D., Osborn, T. J., \& Lister, D. H. (2014). Updated high-resolution grids of monthly climatic observations-the CRU TS3. 10 Dataset. International Journal of Climatology, 34(3), 623-642. 
Hoekstra, A.Y. \& Mekonnen, M.M. (2012). The water footprint of humanity, Proceedings of the National Academy of Sciences, 109(9): 3232-3237.

IEA (International Energy Agency). (2012). Water for Energy: is energy becoming a thirstier resource? Excerpt from the World Energy Outlook 2012. Available from: http://www.worldenergyoutlook.org/media/weowebsite/2012/WEO_2012_Water_Exc erpt.pdf (Accessed on 21/12/2015).

IEA (International Energy Agency). (2015). Statistics. Available from: http://www.iea.org/statistics/statisticssearch/ (Accessed on 15/12/2015).

IIASA and FAO (International Institute for Applied Systems Analysis and Food and Agriculture Organization of the United Nations). (2015). Global Agro-Ecological Zones. Available from: http://www.gaez.iiasa.ac.at/ (Accessed on 15/02/2015).

IPCC (International Panel on Climate Change). (2012). Renewable Energy Sources and Climate Change Mitigation: Special Report of the Intergovernmental Panel on Climate Change.

Kijne, J. W., Barker, R., \& Molden, D. J. (Eds.). (2003). Water productivity in agriculture: limits and opportunities for improvement. CAB International with IWMI, Wallingford, UK.

Lankford, B. (2013). “A Synthesis Chapter: The Incodys Water Security Model.” In Lankford, B., A., Bakker, K., Zeitoun, M. and Conway, D. (eds). Water security: Principles, perspectives and practices. London: Earthscan Publications, pp. 336-352.

Lautze, J \& Manthrithilake, H. (2012). Water Security: Old Concepts, New Package, What Value? Natural Resources Forum 36 (2): 76-87.

Lautze, J., \& Manthrithilake, H. (2014a). 29. Water security: Converging toward common understanding through quantification. In Grafton Q. R., Wyrwoll, P., White, C., and Allendes, D. (Eds). Global Water: Issues and Insights. Available from: http://press.anu.edu.au/apps/bookworm/view/Global+Water\%3A+Issues+and+Insight s/11041/ch06.3.xhtml (Accessed on 21/12/2015).

Lautze, J., \& Manthrithilake, H. (2014b). 4. Water Security. In Lautze, J. (Ed.). Key Concepts in Water Resource Management: A Review and Critical Evaluation. New York: Routledge, pp. 39-56.

Mason, N., \& Calow, R. (2012). Water security: from abstract concept to meaningful metrics: an initial overview of options. Overseas Development Institute, London, UK.

Mekonnen, M. M., Gerbens-Leenes, P. W., \& Hoekstra, A. Y. (2015). The consumptive water footprint of electricity and heat: a global assessment. Environmental Science: Water Research \& Technology, 1(3), 285-297.

MOD16 (MODIS Global Evapotranspiration Project). (Nd). The University of Montana Numerical Terradynamyc Simulation Group. Available from: http://www.ntsg.umt.edu/project/mod16 (Accessed on 15/02/2015).

Molden, D. (Ed). (2007). Summary: Water for Food, Water for Life: A Comprehensive Assessment of Water Management in Agriculture. Available from: http://www.fao.org/nr/water/docs/summary_synthesisbook.pdf (Accessed on 22/09/2016).

Mpala, D. K. (2015). Southern African drought 2015: Another climate change smoking gun? Or is it just poor farming and planning? The New Examiner. Available from: 
http://thenewexaminer.com/southern-african-drought-2015/ (Accessed on 19/09/2016).

New, M., Lister, D., Hulme, M., \& Makin, I. (2002). A high-resolution data set of surface climate over global land areas. Climate research, 21(1), 1-25.

Norman, E. S., Bakker, K., \& Dunn, G. (2011). Recent developments in Canadian water policy: An emerging water security paradigm. Canadian Water Resources Journal, 36(1), 53-66.

Rampa, F., Wyk, L.-A. van. (2014). Regional food security and water in SADC: The potential for sectoral-synergies within CAADP for the implementation of the SADC Regional Agricultural Policy. (ECDPM Discussion Paper 159). Available from: www.ecdpm.org/dp159 (Accessed on 19/09/2016).

Razanajatovo M. (2014). Seychelles Energy Sector. Seychelles Energy Commission. Available from: http://www.visitseychelles.co.kr/Investment/Information/download.asp?FileName=Se ychelles\%20Energy\%20Sector.pdf (Accessed on 19/09/2016).

ReSAKSS (Regional Strategic Analysis and Knowledge Support System). (2015). SADC: Overview. Available from: http://www.resakss.org/Region/sadc (Accessed on 20/09/2016).

SADC (Southern African Development Community). (2005). Regional Water Policy. Available from: http://www.sadc.int/files/1913/5292/8376/Regional_Water_Policy.pdf (Accessed on 22/12/2015).

SADC (Southern African Development Community). (2006). Regional Water Strategy. Available from: http://www.sadc.int/files/2513/5293/3539/Regional_Water_Strategy.pdf (Accessed on 22/12/2015).

SADC (Southern African Development Community). (2015). SADC Industrialization Strategy and Roadmap. Available from: http://www.sadc.int/files/5314/3999/6455/SADC_Industrialisation_Strategy_Roadm ap.pdf (Accessed on 22/12/2015).

Sadoff, C.W., Hall, J.W., Grey, D., Aerts, J.C.J.H., Ait-Kadi, M., Brown, C., Cox, A., Dadson, S., Garrick, D., Kelman, J., McCornick, P., Ringler, C., Rosegrant, M., Whittington, D. and Wiberg, D. (2015). Securing Water, Sustaining Growth: Report of the GWP/OECD Task Force on Water Security and Sustainable Growth, University of Oxford, UK, 180pp.

Shultz, B., \& Uhlenbrook, S. (2007). Water Security: What does it mean, what may it imply? Discussion Paper. UNESCO IHE.

Swaminathan, M. (2001). Ecology and equity: Key determinants of sustainable water security. Water Science and Technology, 43(1): 35-44.

UN (UN's General Assembly Agenda items 13(a) and 115). (2015). Draft outcome document of the United Nations summit for the adoption of the post-2015 development agenda. Available from: http://www.un.org/ga/search/view_doc.asp?symbol=A/69/L.85\&Lang=E (Accessed on $21 / 12 / 2015)$. 
UNESCO IHP (United Nations Educational, Scientific and Cultural Organization International Hydrological Programme). (2015). IHP-VIII: Water Security. Available from: http://www.unesco.org/new/en/natural-sciences/environment/water/ihp-viiiwater-security/ (Accessed on 21/12/2015).

UN-Water. (2014). A Post-2015 Global Goal for Water: Synthesis of Key Findings and recommendations from UN-Water. Available from: http://www.un.org/waterforlifedecade/pdf/27_01_2014_unwater_paper_on_a_post2015_global_goal_for_water.pdf (Accessed on 21/12/2015).

UNU. (2013). Water Security and the Global Water Agenda: UN-Water Analytical Brief. United Nations University Institute. Available from: http://www.unwater.org/downloads/analytical_brief_oct2013_web.pdf (Accessed 21/12/2015).

USEIA (U.S. Energy Information Administration). (2015). International Energy Statistics. Available from: http://www.eia.gov/countries/ (Accessed on 15/06/2015).

WaterAid. (2012). Water Security Framework. WaterAid, London. Available from: http://www.wateraid.org/ /media/Publications/water-security-framework.pdf (Accessed on 21/12/2015).

WHO (World Health Organisation). (2003). WHD Brochure, Part IV: The priorities and solutions for creating healthy places, WHO, Geneva.

WB (World Bank). (2015). Data Indicators, Agricultural land; Agriculture, value added (\% of GDP); Annual freshwater withdrawals, agriculture (\% of total freshwater withdrawal); Annual freshwater withdrawals, industry (\% of total freshwater withdrawal); Annual freshwater withdrawals, total (billion cubic meters); GDP (current US\$); GDP per capita (current US\$); Industry, value added (\% of GDP). Available from: http://data.worldbank.org/indicator (Accessed on 23/11/2015).

WWAP (United Nations World Water Assessment Programme). (2014). The United Nations World Water Development Report 2014: Water and Energy. Paris, UNESCO.

Zeitoun, M. (2011). The global web of national water security. Global Policy, 2(3): 286-296. 